\title{
Overview of Integrated Phytoremediation for Heavy Metals Contaminated Soil
}

\author{
Hong-Giang Hoang', Tzung-Yuh Yeh ${ }^{2 *}$, Chitsan Lin ${ }^{1}$ \\ ${ }^{1}$ Institute of Marine Science and Technology, National Kaohsiung University of Science and Technology, Kaohsiung \\ 81157, Taiwan (R.O.C.) \\ ${ }^{2}$ Department of Civil and Environmental Engineering, National University of Kaohsiung, Taiwan, Kaohsiung 81148, \\ Taiwan (R.O.C.), Tel: 886-7-591-9536, Fax: 886-7-591-9376, E-mail: tyyeh@nuk.edu.tw
}

\begin{abstract}
Heavy metal contaminated soil due to industrial, agricultural and municipal activities is becoming a global concern. Heavy metals severely affect plants, animals and human health. A suitable technology is necessary for heavy metals removal because it cannot self-decomposition as organic compounds. Among the various technologies surveyed, phytoremediation is one of the safest, most innovative, environmental friendly and cost-effective approach for heavy metals removal. Nevertheless, traditional phytoremediation practices pose some limitations such as long processing time, unstable treatment efficiency and limited application at large scale. In many methods proposed to improve phytoremediation, integrated phytoremediation has been studied in the recent years. Integrated phytoremediation use chelating agents and phytohormones to enhance phytoremediation. This is an environmentally safe, saving time and relative high effective method. Results showed that the association of a metal ion and a chelating agent to form chelates helps to maintain the availability of metals in the soil for the uptake of plants. Phytohormones supply nutrients for the soil to support vegetable growth. Therefore, integrated phytoremediation is a promising solution to overcome the disadvantages of conventional phytoremediation. It should be taken commercialization and need more applied projects in this field to demonstrate and clarify the real potential of this technology. In view of above, this manuscript reviews the mechanism and the efficiency of integrated phytoremediation for heavy metals in contaminated soil to give an overview of this technology.
\end{abstract}

Keywords: Phytoremediation; Green Technology; Chelates; Phytohormones

\section{Introduction}

Nowadays, with the rapid rising of industrialization and urbanization, heavy metals pollution is becoming a major concern to the nations of the world. Heavy metals are metals with a density greater than $5 \mathrm{~g} / \mathrm{cm}^{3}$ and generally they are related to pollution and toxicity. However, they also include the metal elements required for some low-level organisms (Adriano, 2001). Heavy metals are classified into three categories: toxic metals ( $\mathrm{Hg}, \mathrm{Cr}, \mathrm{Pb}, \mathrm{Zn}, \mathrm{Cu}, \mathrm{Ni}, \mathrm{Cd}, \mathrm{As}, \mathrm{Co}$, $\mathrm{Sn}, \ldots)$, precious metals ( $\mathrm{Pd}, \mathrm{Pt}, \mathrm{Au}, \mathrm{Ag} \mathrm{Ru}, \ldots)$, and radioactive metals ( $\mathrm{U}, \mathrm{Th}, \mathrm{Ra}, \mathrm{Am}, \ldots)$. Heavy metals present in nature are also present in soil and water and their concentration are increasing in the environment by human activities. Heavy metals by human activities are a major source of heavy metal pollution when they enter the soil and water environments. Some heavy metals such as $\mathrm{As}, \mathrm{Cd}, \mathrm{Cu}, \mathrm{Ni}$ and $\mathrm{Zn}$ are estimated to be more abundant than natural sources (Kabata Pendias, 2010). Heavy metals enter the soil and water due to human action by major pathways such as manure, pesticides, sewage sludge, industries such as mining or deposited from the air. Unlike organic matter, heavy metals are not biodegradable. They are constantly accumulating in the environment and threatening human and animal health (Sarwar et al., 2017). Therefore, heavy metals pollution is attracting much concern from many countries in the world.

Many technologies are used to degrade heavy metals in the soil such as physical, chemical and biological 
technologies. Physical technologies include soil replacement method and thermal desorption method. Soil replacement method is a technology that uses unpolluted soil to replace all or a part of the contaminated soil. This technology has some limitations such as high workload, high cost, and suitable for heavily contaminated soil on small areas. Thermal desorption method is based on the evaporation of pollutants by the use of steam, microwave, infrared radiation. The limitations of this method are expensive, long processing times and limited applicable subjects. Chemical technologies include chemical leaching, chemical fixation, electrolytic remediation and vitrify method. The advantage of chemical technologies is fast processing time. However, it also has many disadvantages, such as high costs, alters soil structure and may produce secondary pollutants (Yao et al., 2012). Biological technologies are the friendly technologies that use plants and microorganisms to degrade pollutants in the environment (Singh et al., 2009). Biological technologies include microbial remediation, phytoremediation and combined approach (Ullah et al., 2015). In particular, phytoremediation is a green technology, eco-friendly technology, low-cost technology. Phytoremediation does not affect soil structure and does not interfere with the ecosystem. Thus, phytoremediation has been recognized as an effective method for remediation of metal contaminated soils (Sarwar et al., 2017).

Besides the advantages, phytoremediation also has disadvantages that need to be addressed. One of the major limitations of phytoremediation is the inhibition of the growth of plant biomass by pollutants such as heavy metals in soil, an important factor in the success of phytoremediation (Sun et al., 2012). In addition, the availability of heavy metals in the soil also decides the effectiveness of phytoremediation (Hadi et al., 2010; Sun et al., 2012). To address these disadvantages of phytoremediation, the integration of chelators and plant growth regulators has been used and yielded remarkable results (Fässler et al., 2010; Hadi et al., 2010; Liu et al., 2007). The chelators have been proposed to increase the availability of metals in the soil, helping to increase the absorption of heavy metals by plants (Alkorta et al., 2004; Luo et al., 2004). According to Evangelou et al. (2007), there are two classes of chelates commonly used: persistent aminopolycarboxylic acids (APCAs) and biodegradable APCAs. Persistent aminopolycarboxylic acids (APCAs) such as EDTA are low biodegradable. Thus, they are no longer recommended. Instead, biodegradable APCAs such as ethylene diamine disuccinate (EDDS) and nitrilo triacetic acid (NTA) are the best choice for improving heavy metals uptake by plants. Plant growth regulators have been proposed to stimulate the development of plant biomass in contaminated soil conditions (Chen et al., 2012). "Plant growth regulators are organic substances, which in low concentration promote or inhibit the growth" (Sharma \& Kumar, 2011). Plant growth regulators can regulate intracellular processes and promote cell activation to improve plant growth (Hadi et al., 2010). The most popular plant growth regulators are IAA, IBA, NAA and GA3 (Bulak et al., 2013). Combination of chelators and phytohormones, integrated phytoremediation, has solved the greatest limitation of phytoremediation. It can be widely used in the treatment of heavy metal contaminated soil and bring the phytoremediation technology to new heights in recent years.

In order to an overview of integrated phytoremediation, this manuscript reviews the mechanism and the efficiency of integrated phytoremediation for heavy metals in contaminated soil. In addition, this study has the synthetical presentation of chelators and phytohormones used for integrated phytoremediation and compare their efficacy in enhancing phytoremediation for heavily contaminated soils.

\section{Sources of heavy metals in contaminated soils}

Heavy metals are important natural components in the soil to organize the life on Earth. Nevertheless, with the development of industrial revolutions, the concentration of heavy metals in the soil has been increasing rapidly in the recent years and heavy metals has become one of the most noteworthy contaminants in contaminated soil (Jing et al., 2007). The toxicity of heavy metals in the soil varies for different subjects. Their toxicity affects ecosystem, evolution, nutrition and the environment (Nagajyoti et al., 2010). The most common toxic metals in the soil are $\mathrm{Hg}, \mathrm{Pb}, \mathrm{Cd}, \mathrm{Cu}, \mathrm{Cr}$, Mn, Zn, Al (Adriano, 2001; Duruibe et al., 2007). Heavy metals enter the body through pathways such as food, water, air and skin contact. Heavy metals become toxic when they are not metabolized by the body and accumulate in the soft tissues (Wuana \& Okieimen, 2011). Recent data indicate that after several years of exposure, heavy metals can affect human health such as cancer (skin, lung, ...), kidney, bone disorders, neurological depression, chronic anemia, 
affects the fetus... (Järup, 2003)

Contamination of heavy metals in the soil can be from natural or anthropogenic sources. The most important natural source of heavy metals in the soil is from the formation of the Earth's crust from geologic parent material or rock outcroppings. Stone type and environmental conditions determine the components and concentration of heavy metals in the soil. When weathering occurs, they contribute to the soil some typical metals such as $\mathrm{Cr}, \mathrm{Mn}, \mathrm{Co}, \mathrm{Ni}, \mathrm{Cu}, \mathrm{Zn}, \mathrm{Cd}, \mathrm{Sn}$, $\mathrm{Hg}, \mathrm{Pb}$ (Nagajyoti et al., 2010). Another source, volcanic eruptions also contribute to increasing concentrations of heavy metals ( $\mathrm{Al}, \mathrm{Zn}, \mathrm{Mn}, \mathrm{Pb}, \mathrm{Ni}, \mathrm{Cu}$ and $\mathrm{Hg}$ ) in the soil. In addition, wind dust, marine aerosols and forest fires also have a significant effect on the concentration of heavy metals ( $\mathrm{Mn}, \mathrm{Zn}, \mathrm{Cr}$, Ni and $\mathrm{Pb}$ ) in many environments (Ross, 1994).

The anthropogenic sources of heavy metals in the soil include agricultural, industrial activities, wastewater, atmospheric deposition and other sources. Fertilizers and pesticides are used to increase the growth of crops in agriculture. However, the use too much of fertilizers and pesticides is one of the sources of heavy metals $(\mathrm{Cu}, \mathrm{Hg}, \mathrm{Mn}$, $\mathrm{Pb}, \mathrm{Cd}$, or $\mathrm{Zn}$ ) in the contaminated soil (Wuana \& Okieimen, 2011). For industrial sources, heavy metals arise primarily from the mining industry. In the process of the mining industry, tailings are discharged into the natural environment, go to the food chain and affect the organism and the people. In addition, other industries such as textile, tanning, refinement and pharmaceutical facilities are also able to release heavy metals $(\mathrm{Cr}, \mathrm{Pb}, \mathrm{Zn}$...) into the environment (Nagajyoti et al., 2010). Wastewater is usually treated and controlled by standards before being discharged into the environment. However, the use of this wastewater for long-term irrigation can lead to the accumulation of heavy metals in the soil. Another pollutant source of heavy metals contaminated soil is the deposition of airborne particulates that contain metals from the atmosphere. Airborne particulates are deposited on the lithosphere through processes such as rain and snowfall. Other sources of heavy metals are refuse to burn, burial, transport (generating $\mathrm{Cd}, \mathrm{Cr}, \mathrm{Cu}, \mathrm{Ni}, \mathrm{Pb}$, $\mathrm{Zn}$...), coal and oil (generating As, $\mathrm{Cd}, \mathrm{Cr}, \mathrm{Co}, \mathrm{Cu}, \mathrm{Pb}, \mathrm{Mn}, \mathrm{Hg}, \mathrm{Ni}, \mathrm{Se}$, and $\mathrm{Zn}$ ) (Kida et al., 1996; Meij \& te Winkel, 2007; Reddy et al., 2005).

\section{Phytoremediation}

The term phytoremediation was formed by phyto (Greek phyton: related to plant) and remedium, which means to cleanup (Mahar et al., 2016). "Phytoremediation basically refers to the use of plants and associated soil microbes to reduce the concentrations or toxic effects of contaminants in the environments" (Greipsson, 2011). Phytoremediation is a new green technology in last two decades that is used for the uptake of pollutants from contaminated soils and storage of these in the parts of plant (Kamran et al., 2014). It can be used for removal of heavy metals and radionuclides as well as for organic pollutants such as pesticides, polychlorinated dibenzo-p-dioxins, polychlorinated dibenzo-p-furans and polychlorinated biphenyls (Ali et al., 2013). Among technologies to remove pollutants in the contaminated soils, phytoremediation is considered as a clean, green and environmental friendly technology (Mahar et al., 2016). There is no intervention into ecosystem when using this technology (Cristaldi et al., 2017). Vegetation on contaminated soils can prevent erosion, improve soil and bring aesthetics (Ali et al., 2013; Sarwar et al., 2017). In addition, it is considered as a technology that requires less manpower, initial and maintenance costs lower than other traditional methods (Ali et al., 2013; Cristaldi et al., 2017). The advantages and disadvantages of phytoremediation are listed in Table 1. Therefore, phytoremediation is an optimail option to remove heavy metals as well as other pollutants in contaminated soils.

\begin{tabular}{|l|l|}
\hline Advantages & Limitations \\
\hline Aesthetically pleasing & The time consuming method \\
Less disruptive than current techniques & The amount of produced biomass \\
The effectiveness in contaminant reduction & The root depth \\
Low cost & Soil chemistry \\
Applicable for wide range of contaminants & Level of contamination \\
Environmentally friendly method & The age of plant \\
& The contaminant concentration \\
& The impacts of contaminated vegetation \\
& Climatic condition \\
\hline
\end{tabular}


Table 1. Advantages and limitations of the phytoremediation technology

According to Alkorta et al. (2004) mechanisms of phytoremediation include phytoextraction (or phytoaccumulation), phytofiltration, phytostabilization, phytovolatilization and phytodegradation. Phytoextraction is removal pollutants from soil and concentrate them in the harvestable parts of plants by using plants. Phytofiltration is absorbtion of pollutants (mostly, metals) from contaminated soils by plants roots (rhizofiltration) or seedlings (blastofiltration). Phytostabilization is immobilisation or prevention of migration of pollutants by using plants to reduce its mobility and bioavailability in the environment. Phytovolatilization is the use of plants to volatilize pollutants into the atmosphere. Phytodegradation is the use of plants and associated microbes to degrade organic pollutants.

The goals of phytoremediation are (1) prevent and reduce risks; (2) use plants to extract heavy metals and other pollutants and (3) sustainable soil resources management in order to bring economic value for agriculture (Vangronsveld et al., 2009).

\section{Integrated phytoremediation}

\subsection{Chelating agents enhanced phytoremediation}

The idea of using chelate-enhanced phytoremediation to remove heavy metals in polluted soils has studied in a recent decade (Evangelou et al., 2007). According to Alkorta et al. (2004), "A chelate is a chemical compound composed of a metal ion and a chelating agent". The formation of chelates helps to maintain the availability of metals in the soil for the uptake of plants. Chelates have been proposed to increase the absorption of heavy metals by plants without decrease hyperaccumulating efficiency of plants (Leštan et al., 2007). Chelates are effective in increasing the mobility of metals in the soil and using vegetation to transport heavy metals from the root to the shoot of the plant (Yeh et al., 2014).

According to (Evangelou et al. (2007)), the commonly used chelates are persistent amino polycarboxylic acids (APCAs) (such as EDTA, HEDTA, DTPA, CDPA, EGTA...), biodegradable APCAs (such as EDDS, NTA..., natural low molecular weight organic acids (NLMWOA) and humic substances (HS). The chelates are listed in the table 2.

\begin{tabular}{|l|l|}
\hline Abbreviations & Full name \\
\hline EDTA & Ethylenediaminetetraacetic acid \\
HEDTA & N-hydroxyethylethylenediaminetriacetic acid \\
CDTA & Diethylenetriaminopentaacetic acid \\
EGTA & Trans-1,2-diaminocyclohexane-N,N,N $\not \subset, N \not \subset$-tetraacetic acid \\
EDDHA & Ethylenebis(oxyethylenetrinitrilo)- N,N,N $\not$,N $\varnothing$-tetraacetic acid \\
HEIDA & Ethylenediamine-di (o-hydroxyphenylacetic acid) \\
EDDS & N-(2-hydroxyethyl)iminodiacetic acid \\
NTA & Ethylenediaminesuccinate \\
HBED & Nitrilotriacetic acid \\
CA & N,N-di(2-hydroxybenzyl)ethyleneamide N,N $\not \subset$-diacetic acid \\
MA & Citric acid \\
\hline
\end{tabular}

Table 2. Some chelating agents used in phytoremediation studies

In which, the four most frequently used chelates are EDTA, EDDS, DTPA and CA (Yeh et al., 2014). In previous years, EDTA was widely used because of its high efficiency in treating heavy metals in the soil. However, due to its low biodegradability and its ability to survive in groundwater, it has proposed to replace by highly biodegradable chelates such as EDDS in recent years (Luo et al., 2004).

The effectiveness of using chelates in support of phytoremediation depends on the choice of plant species and the types of metals stored in the soil (Yeh et al., 2014). Some recent studies have shown and compared the effectiveness of using different chelates to enhance phytoremediation. Huang et al. (1997) reported the order of effectiveness in increasing $\mathrm{Pb}$ accumulation in both pea (P. sativum L. cv. Sparkle) and corn (Z. mays L. cv. Fiesta) as the following: EDTA $>$ HEDTA $>$ DTPA $>$ EGTA $>$ EDDHA. In the paper by Chiu et al. (2005), HEIDA was more effective than HEDTA, CDTA, EDTA, DTPA and EGTA in mobilizing $\mathrm{Cu}$ in the soil. Table 3 summarizes the effectiveness of chelating agents enhanced phytoremediation in several recent studies 


\begin{tabular}{|c|c|c|c|c|c|c|}
\hline Chelating Agents & Plants & $\begin{array}{l}\text { Heavy } \\
\text { metals }\end{array}$ & $\begin{array}{l}\text { Initial } \\
\text { concentration }\end{array}$ & $\begin{array}{l}\text { Fold increase in metal } \\
\text { accumulation }(*)\end{array}$ & $\begin{array}{l}\text { Uptake } \\
\text { by }\end{array}$ & Reference \\
\hline \multirow{4}{*}{ EDDS $500 \mu \mathrm{mol} / \mathrm{kg}$} & \multirow{4}{*}{ Sunflower } & $\mathrm{Pb}$ & $2000 \mathrm{mg} / \mathrm{kg}$ & 1.85-fold & \multirow{4}{*}{$\begin{array}{l}\text { Entire } \\
\text { plant }\end{array}$} & \multirow{4}{*}{$\begin{array}{l}\text { (Yeh et al., } \\
\text { 2016) }\end{array}$} \\
\hline & & $\mathrm{Ni}$ & $200 \mathrm{mg} / \mathrm{kg}$ & 1.02-fold & & \\
\hline & & $\mathrm{Pb}$ & $4000 \mathrm{mg} / \mathrm{kg}$ & 1.37-fold & & \\
\hline & & $\mathrm{Ni}$ & $400 \mathrm{mg} / \mathrm{kg}$ & 1.92-fold & & \\
\hline \multirow{2}{*}{ EDTA $5 \mathrm{mmol} / \mathrm{kg}$} & \multirow{8}{*}{$\begin{array}{l}\text { Chinesse } \\
\text { Cabbage }\end{array}$} & $\mathrm{Cu}$ & $1000 \mathrm{mg} / \mathrm{kg}$ & 2.63-fold & \multirow{8}{*}{ Roots } & \multirow{8}{*}{$\begin{array}{l}\text { (Yeh et al., } \\
\text { 2014) }\end{array}$} \\
\hline & & $\mathrm{Zn}$ & $8000 \mathrm{mg} / \mathrm{kg}$ & 2.56-fold & & \\
\hline \multirow[t]{2}{*}{ DTPA $5 \mathrm{mmol} / \mathrm{kg}$} & & $\mathrm{Cu}$ & $1000 \mathrm{mg} / \mathrm{kg}$ & 2.98-fold & & \\
\hline & & $\mathrm{Zn}$ & $8000 \mathrm{mg} / \mathrm{kg}$ & 2.82-fold & & \\
\hline \multirow{2}{*}{ EDDS 5 mmol $/ \mathrm{kg}$} & & $\mathrm{Cu}$ & $1000 \mathrm{mg} / \mathrm{kg}$ & 1.99-fold & & \\
\hline & & $\mathrm{Zn}$ & $8000 \mathrm{mg} / \mathrm{kg}$ & 2.29-fold & & \\
\hline \multirow{2}{*}{ CA $5 \mathrm{mmol} / \mathrm{kg}$} & & $\mathrm{Cu}$ & $1000 \mathrm{mg} / \mathrm{kg}$ & 1.16-fold & & \\
\hline & & $\mathrm{Zn}$ & $8000 \mathrm{mg} / \mathrm{kg}$ & 1.44-fold & & \\
\hline $\mathrm{CA} 5 \mathrm{mmol} / \mathrm{kg}$ & \multirow{4}{*}{ Sedum alfredii } & \multirow{4}{*}{$\mathrm{Cd}$} & \multirow{4}{*}{$3.03 \mathrm{mg} / \mathrm{kg}$} & 3.37-fold & \multirow{4}{*}{ Shoots } & \multirow{4}{*}{$\begin{array}{l}\text { (Sun et al., } \\
\text { 2009) }\end{array}$} \\
\hline $\mathrm{CA} 8 \mathrm{mmol} / \mathrm{kg}$ & & & & 4.56-fold & & \\
\hline EDTA $5 \mathrm{mmol} / \mathrm{kg}$ & & & & 3.94-fold & & \\
\hline EDTA $8 \mathrm{mmol} / \mathrm{kg}$ & & & & 4.86-fold & & \\
\hline $\begin{array}{l}\text { Oxilic acid } \\
0.05 \mathrm{mmol} / \mathrm{kg}\end{array}$ & \multirow{4}{*}{$\begin{array}{l}\text { Brassica } \\
\text { juncea }\end{array}$} & \multirow{4}{*}{$\mathrm{Cr}$} & \multirow{4}{*}{$3100 \mathrm{mg} / \mathrm{kg}$} & 2.36-fold & \multirow{4}{*}{ Roots } & \multirow{4}{*}{$\begin{array}{l}\text { (Hsiao et al., } \\
\text { 2007) }\end{array}$} \\
\hline $\begin{array}{l}\text { Citric acid } \\
0.05 \mathrm{mmol} / \mathrm{kg} \\
\end{array}$ & & & & 1.27-fold & & \\
\hline $\begin{array}{l}\text { EDTA } \\
0.05 \mathrm{mmol} / \mathrm{kg}\end{array}$ & & & & 2-fold & & \\
\hline $\begin{array}{l}\text { DTPA } \\
0.05 \mathrm{mmol} / \mathrm{kg}\end{array}$ & & & & 1.9-fold & & \\
\hline EDDS $2 \mathrm{mmol} / \mathrm{kg}$ & $\begin{array}{l}\text { Coronopus } \\
\text { didymus }\end{array}$ & $\mathrm{Ni}$ & $70 \mathrm{mg} / \mathrm{kg}$ & 2.01-fold & Roots & $\begin{array}{l}\text { (Sidhu et al., } \\
\text { 2018) }\end{array}$ \\
\hline
\end{tabular}

$\left(^{*}\right)$ Compared to control sample (only heavy metals)

Table 3. The effectiveness of chelates enhanced phytoremediation

\subsection{Plant growth regulators enhanced phytoremediation}

Previous studies have shown that the slowly growing ability of plants in contaminated soil is a major limitation of phytoremediation (Denton, 2007; Kos \& Leštan, 2004; López et al., 2007). Heavy metal contaminated soils often inhibit the growth of crops leading to reduce the absorption ability of heavy metals of plants. The development of the root surface area can increase the absorption of heavy metals of plants (Fässler et al., 2010). Accordingly, plant growth regulators (PGR) is proposed as a substance that can stimulate cell division, cell proliferation and root growth (Taiz et al., 2000). "PGR are organic substances, which in low concentration promote or inhibit the growth" (Sharma \& Kumar, 2011). Plant growth regulators can regulate intracellular processes and promote cell activation to improve plant growth (Hadi et al., 2010).

There are five groups of PGR: auxins, cytokinins, gibberellins, ethylene and abscisic acid (Bulak et al., 2013). In which auxins and cytokinins are the most important phytohormones (George et al., 2008). Auxins are directly embarked on cation uptake and have an important impact on tropisms (Vamerali et al., 2011). The most common auxins are indole-3-acetic acid (IAA), indole-3-butyric acid (IBA), and weak auxin phenylacetic acid (PAA) (George et al., 2008). Cytokinins (CKs) are phytohormones affecting numerous developmental processes. Cytokinins accelerate cell division, shoot formation and accumulation of chlorophyll (Bulak et al., 2013). Zeatin and its derivatives are the most important group of CKs. Gibberellins enhance the process flowering, seed germination, stem elongation, leaf expansion in plant 
growth (Khan \& Chaudhry, 2006). The most widely used gibberellin is gibberellic acid (GA3). Ethylene regulates numerous plant processes, such as seed germination, root-hair initiation and leaf and flower senescence and abscission (Bleecker \& Kende, 2000). Abscisic acid can assist the plant growth and developmental processes, such as embryo maturation, seed dormancy (Leung \& Giraudat, 1998).

In order to stimulate plant growth and plant biomass, shoot and root are important positions to promote growth by phytohormones. According to Sharma and Kumar (2011), Indole-3-acetic acid (IAA) and $\alpha$-Naphthalene acetic acid (NAA) promote root formation but inhibit the shoot length. Contrarily, Indole-3-butyric acid (IBA) promotes the shoot length and inhibits the root length. Gibberellic acid (GA3) application to the shoot enhances both shoot and root elongation.

The use of PGR to support phytoremediation of heavy metals removal in soil has yielded positive results. Some typical research results are listed in the table 4.

\begin{tabular}{|c|c|c|c|c|c|c|}
\hline $\begin{array}{l}\text { Plant growth } \\
\text { regulators }\end{array}$ & Plants & $\begin{array}{l}\text { Heavy } \\
\text { metals }\end{array}$ & $\begin{array}{l}\text { Initial } \\
\text { concentration }\end{array}$ & $\begin{array}{l}\text { Fold increase in metal } \\
\text { accumulation }(*)\end{array}$ & $\begin{array}{l}\text { Uptake } \\
\text { by }\end{array}$ & References \\
\hline GA3 $15 \mathrm{mg} / \mathrm{L}$ & \multirow{3}{*}{$\begin{array}{l}\text { Cannabis } \\
\text { sativa }\end{array}$} & \multirow{3}{*}{$\mathrm{Cd}$} & \multirow{3}{*}{$100 \mathrm{mg} / \mathrm{kg}$} & 7.62-fold & \multirow{3}{*}{$\begin{array}{l}\text { Entire } \\
\text { plant }\end{array}$} & \multirow{3}{*}{$\begin{array}{l}\text { (Ahmad et al., } \\
\text { 2014) }\end{array}$} \\
\hline IAA $15 \mathrm{mg} / \mathrm{L}$ & & & & 5.46-fold & & \\
\hline Zeatin $15 \mathrm{mg} / \mathrm{L}$ & & & & 4.33 -fold & & \\
\hline \multirow{4}{*}{$\begin{array}{l}\mathrm{GA} 3(1,3 \text { and } 5 \\
\mathrm{mmol} / \mathrm{kg})\end{array}$} & \multirow{4}{*}{$\begin{array}{l}\text { Tagetes } \\
\text { patula }\end{array}$} & \multirow{4}{*}{$\mathrm{Cd}$} & \multirow{4}{*}{$0.2 \mathrm{mg} / \mathrm{kg}$} & $12-50 \%$ & Roots & \multirow{4}{*}{$\begin{array}{l}\text { (Sun et al., } \\
\text { 2012) }\end{array}$} \\
\hline & & & & $16-20 \%$ & Stems & \\
\hline & & & & $16-40 \%$ & Leaves & \\
\hline & & & & $15-33 \%$ & Shoots & \\
\hline GA3 $\left(10^{-6} \mathrm{M}\right)$ & \multirow[t]{2}{*}{$\begin{array}{l}\text { Zea mays } \\
\text { L. }\end{array}$} & \multirow[t]{2}{*}{$\mathrm{Pb}$} & \multirow[t]{2}{*}{$800 \mathrm{mg} / \mathrm{kg}$} & 2.7-fold & \multirow[t]{2}{*}{$\begin{array}{l}\text { Entire } \\
\text { plant }\end{array}$} & \multirow[t]{2}{*}{$\begin{array}{l}\text { (Hadi et al., } \\
\text { 2010) }\end{array}$} \\
\hline $\operatorname{IAA}\left(10^{-6} \mathrm{M}\right)$ & & & & 2.8-fold & & \\
\hline IBA $2.5 \mu \mathrm{M}$ & \multirow{3}{*}{$\begin{array}{l}\text { Brassica } \\
\text { juncea }\end{array}$} & \multirow{3}{*}{$\mathrm{Au}$} & \multirow{3}{*}{$5 \mathrm{mg} / \mathrm{kg}$} & 2.24-fold & \multirow{3}{*}{ Roots } & \multirow{3}{*}{$\begin{array}{l}\text { (Kulkarni et al., } \\
\text { 2012) }\end{array}$} \\
\hline IBA $5 \mu \mathrm{M}$ & & & & 6.48 -fold & & \\
\hline IBA $7.5 \mu \mathrm{M}$ & & & & 3.53-fold & & \\
\hline \multirow{4}{*}{ Cytokin 100mg/l } & \multirow{4}{*}{ Sunflower } & \multirow{2}{*}{$\mathrm{Pb}$} & \multirow{2}{*}{$440 \mathrm{mg} / \mathrm{kg}$} & 2-fold & Leaves & \multirow{4}{*}{$\begin{array}{l}\text { (Tassi et al., } \\
\text { 2007) }\end{array}$} \\
\hline & & & & 1.57-fold & Shoots & \\
\hline & & \multirow{2}{*}{$\mathrm{Zn}$} & \multirow{2}{*}{$128 \mathrm{mg} / \mathrm{kg}$} & 2-fold & Leaves & \\
\hline & & & & 1.21-fold & Shoots & \\
\hline
\end{tabular}

(*) Compared to control sample (only heavy metals)

Table 4. The effectiveness of plant growth regulators enhanced phytoremediation

\subsection{Chelating agents and plant growth regulators enhanced phytoremediation}

The success of phytoremediation of heavy metal removal depends on two factors (1) the bioavailability of the metal and (2) the metal accumulated ability in the plant biomass (Hadi et al., 2010). Using chelators increase the solubility of metals in the soil and create the availability of heavy metals in the soil, that makes it easier accumulate by the plant (Liphadzi et al., 2010; Salt et al., 1998). However, the availability of metals in the soil can increase the pressure on plants, inhibit plant growth, and lead to reduce heavy metal absorption of the plant (Denton, 2007; Hadi et al., 2014; Tandy et al., 2006). This adverse effect of chelators on plants can be reduced by adding phytohormones to the soil as fertilizer to improve soil quality and stimulate the growth of plants (Falkowska et al., 2011; Fässler et al., 2010). The combination of chelators and phytohormones is used as a new strategy to improve the effectiveness of phytoremediation. It helps to overcome the disadvantages and promotes the advantages of phytoremediation for treating heavy metals in the soil.

The success in the combination of chelators and phytohormones to treat heavy metals in soils has been shown in 
several recent studies. According to Lopez et al. (2010), incorporating EDTA and IAA into Alfalfa plants for treating lead-contaminated soil has a good result. The result indicates that, for control samples (only $\mathrm{Pb}$ ), the lead was not detected in the stems. But when using integrated EDTA-IAA-KN, the amount of lead detected in the stems was 142 $\mathrm{mg} / \mathrm{kg}$ DW. According to Hadi et al. (2014), using combined EDTA and GA3 on Parthenium hysterophorus to treat cadmium contaminated soil has significantly increased efficiency. The treatment efficiency was increased by more than 7-fold compared with the control sample (only $\mathrm{Cd}$ ). Some typical results of integrated phytoremediation are summarized in the table 5 .

In addition, the authors have also done some research to demonstrate effective phytoremediation enhancement using integrated chelators and plant growth regulators for plants. The study on Integrated Phytoremediation Measures for Enhancing Energy Crops' Performance in Treating Heavy Metal-polluted Soil was conducted at National Kaohsiung University. The purpose of this research is to verify a set of integrated measures for the phytoremediation of soil polluted by heavy metals. With the addition of chelant, phytohormone and calcium peroxide into the soil, we then grow energy-related crops, i.e. sunflowers, on it to absorb the heavy metals into the plant's body, reducing its content level and consequently achieving the goal of phytoremediation. In this research, we used a pot experiment to investigate the optimal operational parameters for phytoremediation by adding chelant (EDTA, EDDS), phytohormone (GA3, IAA), and calcium peroxide into soil polluted by copper, zinc and lead. The experiment's results indicate that EDDS is suitable for soil polluted by copper or zinc, while EDTA is the best one for removing lead from the soil. While both IAA and GA3 can increase the biomass of plants, GA3 performs better. Therefore, our conclusions regarding the optimal operational parameters for phytoremediation are as follows: The combination of GA3+EDDS+ $\mathrm{CaO} 2$ is the best formula to remove copper and zinc, while GA3+EDTA+CaO2 is the most suitable one for eliminating lead from the soil. Compared with the conventional methods of phytoremediation, these integrated measures can actually spur the growth of plants and improve the efficiency of their absorption of heavy metals.

\begin{tabular}{|c|c|c|c|c|c|c|c|}
\hline $\begin{array}{l}\text { Chelating } \\
\text { Agents }\end{array}$ & $\begin{array}{c}\text { Plant } \\
\text { growth } \\
\text { regulators } \\
\end{array}$ & Plants & $\begin{array}{c}\begin{array}{c}\text { Hea } \\
\text { vy } \\
\text { metals }\end{array} \\
\end{array}$ & $\begin{array}{c}\text { Initial } \\
\text { concentration }\end{array}$ & $\begin{array}{c}\text { Fold increase } \\
\text { in metal } \\
\text { accumulation }(*)\end{array}$ & $\begin{array}{l}\text { Uptak } \\
\text { e by }\end{array}$ & Ref. \\
\hline \multirow{4}{*}{$\begin{array}{l}\text { EDDS } \\
(100 \mathrm{ml}, \\
500 \mu \mathrm{mol} / \mathrm{kg})\end{array}$} & \multirow{4}{*}{$\begin{array}{l}\text { GA3 } \\
\left(10^{-8}\right. \\
\text { mol/kg })\end{array}$} & \multirow{4}{*}{ Sunflower } & $\mathrm{Pb}$ & $2000 \mathrm{mg} / \mathrm{kg}$ & 1.26-fold & \multirow{4}{*}{$\begin{array}{l}\text { Entire } \\
\text { plant }\end{array}$} & \multirow{4}{*}{$\begin{array}{l}\text { (Yeh } \\
\text { et al., } \\
2016)\end{array}$} \\
\hline & & & $\mathrm{Ni}$ & $200 \mathrm{mg} / \mathrm{kg}$ & 2.34-fold & & \\
\hline & & & $\mathrm{Pb}$ & $4000 \mathrm{mg} / \mathrm{kg}$ & 1.92-fold & & \\
\hline & & & $\mathrm{Ni}$ & $400 \mathrm{mg} / \mathrm{kg}$ & 2.26-fold & & \\
\hline \multirow{2}{*}{$\begin{array}{l}\text { EDDS } \\
(100 \mathrm{ml}, \\
500 \mu \mathrm{mol} / \mathrm{kg})\end{array}$} & \multirow{2}{*}{$\begin{array}{l}\text { GA3 } \\
\left(10^{-8}\right. \\
\mathrm{mol} / \mathrm{kg})\end{array}$} & \multirow{2}{*}{ Sunflower } & $\mathrm{Cu}$ & $800 \mathrm{mg} / \mathrm{kg}$ & 2.13-fold & \multirow{2}{*}{$\begin{array}{l}\text { Entire } \\
\text { plant }\end{array}$} & \multirow{2}{*}{$\begin{array}{l}\text { (Yeh } \\
\text { et al., } \\
2017)\end{array}$} \\
\hline & & & $\mathrm{Zn}$ & $4000 \mathrm{mg} / \mathrm{kg}$ & 3.09-fold & & \\
\hline $\begin{array}{c}\text { EDTA } \\
(400 \mathrm{mg} / \mathrm{kg})\end{array}$ & $\begin{array}{l}\text { IAA }\left(10^{-6}\right. \\
\text { M) }\end{array}$ & \multirow{2}{*}{$\begin{array}{l}\text { Zea mays } \\
\text { L. }\end{array}$} & $\mathrm{Pb}$ & $800 \mathrm{mg} / \mathrm{kg}$ & 5.4-fold & \multirow{2}{*}{$\begin{array}{l}\text { Entire } \\
\text { plant }\end{array}$} & \multirow{2}{*}{$\begin{array}{l}\text { (Hadi } \\
\text { et al., } \\
2010)\end{array}$} \\
\hline $\begin{array}{c}\text { EDTA } \\
(400 \mathrm{mg} / \mathrm{kg}) \\
\end{array}$ & $\begin{array}{l}\text { GA3 }\left(10^{-6}\right. \\
\text { M) }\end{array}$ & & $\mathrm{Pb}$ & $800 \mathrm{mg} / \mathrm{kg}$ & 5.2-fold & & \\
\hline $\begin{array}{c}\text { EDTA } \\
(200 \mu \mathrm{M})\end{array}$ & $\begin{array}{c}\text { IAA } \\
(1 \mu \mathrm{M})\end{array}$ & \multirow{3}{*}{ S.alfredii } & \multirow{3}{*}{$\mathrm{Pb}$} & \multirow{3}{*}{$200 \mu \mathrm{M}$} & 1.73-fold & \multirow{3}{*}{ Shoots } & \multirow{3}{*}{$\begin{array}{l}\text { (Liu } \\
\text { et al., } \\
2007)\end{array}$} \\
\hline $\begin{array}{r}\text { EDTA } \\
(200 \mu \mathrm{M})\end{array}$ & $\begin{array}{r}\text { IAA } \\
(10 \mu \mathrm{M}) \\
\end{array}$ & & & & 2.49-fold & & \\
\hline $\begin{array}{r}\text { EDTA } \\
(200 \mu \mathrm{M}) \\
\end{array}$ & $\begin{array}{c}\text { IAA } \\
(100 \mu \mathrm{M})\end{array}$ & & & & 3.43-fold & & \\
\hline $\begin{array}{l}\text { EDTA } \quad(160 \\
\mathrm{mg} / \mathrm{kg})\end{array}$ & $\begin{array}{c}\text { GA3 } \\
\left(10^{-7} \mathrm{M}\right)\end{array}$ & \multirow{2}{*}{$\begin{array}{l}\text { Parthenium } \\
\text { hysterophorus }\end{array}$} & \multirow{2}{*}{$\mathrm{Cd}$} & \multirow{2}{*}{$100 \mathrm{mg} / \mathrm{kg}$} & 6.75-fold & \multirow{2}{*}{$\begin{array}{l}\text { Entire } \\
\text { plant }\end{array}$} & \multirow{2}{*}{$\begin{array}{l}\text { (Hadi } \\
\text { et al., } \\
2014)\end{array}$} \\
\hline $\begin{array}{cc}\begin{array}{c}\text { EDTA } \\
\mathrm{mg} / \mathrm{kg})\end{array} & (40 \\
\end{array}$ & $\begin{array}{c}\text { GA3 } \\
\left(10^{-7} \mathrm{M}\right) \\
\end{array}$ & & & & 7.81-fold & & \\
\hline \multirow{2}{*}{$\begin{array}{l}\text { EDTA } \\
(1 \mathrm{~g} / \mathrm{kg})\end{array}$} & \multirow{2}{*}{$\begin{array}{r}\text { IAA } \\
(6 \mathrm{mg} / \mathrm{l})\end{array}$} & \multirow{2}{*}{ Sunflower } & $\mathrm{Fe}$ & & 1.33-fold & \multirow{2}{*}{$\begin{array}{l}\text { Entire } \\
\text { plant }\end{array}$} & \multirow{2}{*}{$\begin{array}{l}\text { (Lipha } \\
\text { dzi et al., } \\
2010)\end{array}$} \\
\hline & & & $\mathrm{Cd}$ & & 1.17-fold & & \\
\hline
\end{tabular}




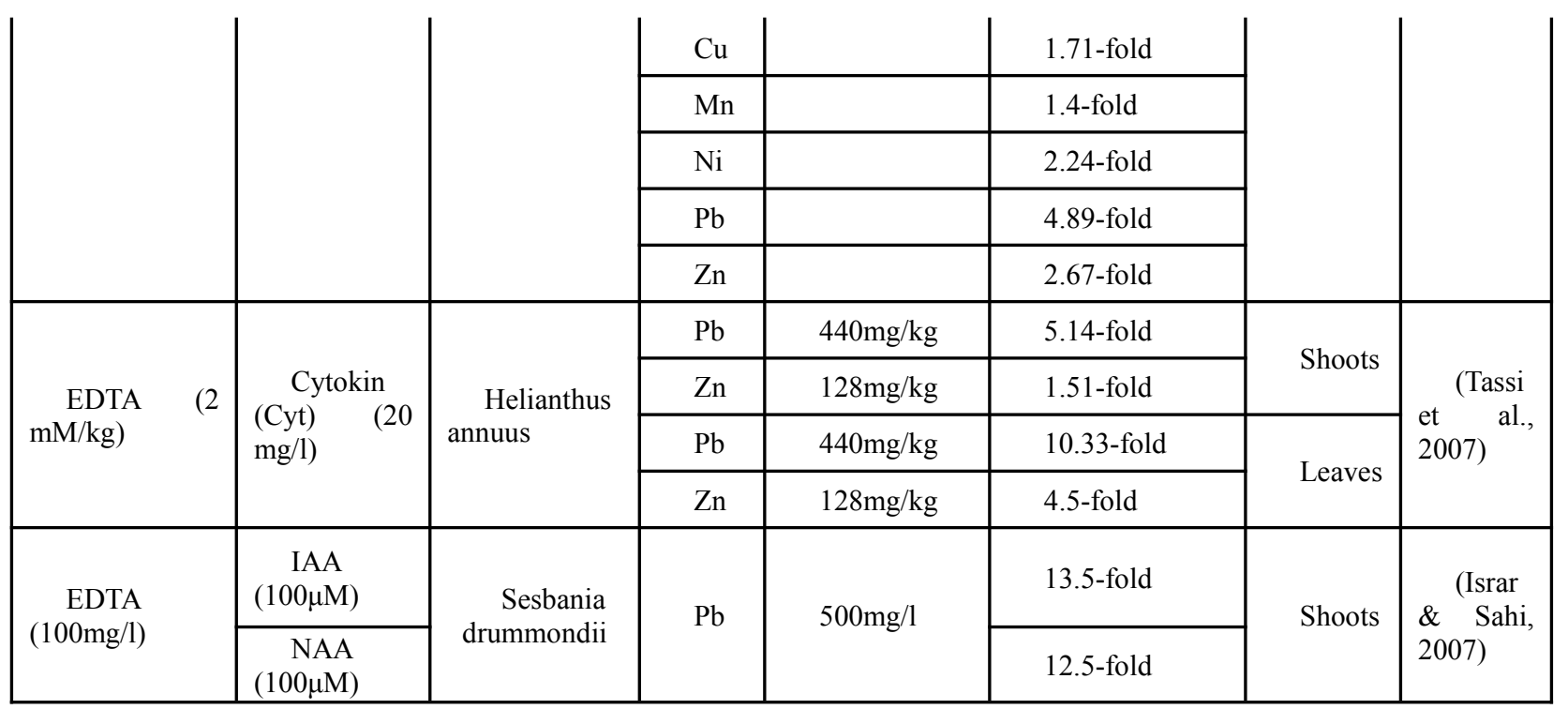

Table 5. The effectiveness of integrated phytoremediation

\section{Conclusions}

In recent decades, the approach of chelators and phytohormones assisted phytoremediation has been a promising technique for overcoming heavy metal contaminated soil. The performed studies have shown the potential of using integrated chelators and phytohormones to enhance phytoremediation. Chelates increase the bioavailability of heavy metals in the soil while phytohormones stimulate to increase roots length, shoot growth and biomass accumulation under conditions of heavy metal contamination. The combination of chelators and phytohormones helps overcome the limitations and promotes the advantages of phytoremediation to treat heavy metals in the soil. This is considered as a new strategy to improve the effectiveness of phytoremediation.

\section{References}

1. Adriano, D.C. 2001. Introduction. in: Trace elements in terrestrial environments; biogeochemistry, bioavailability and risks of metals, Springer, pp. 1-28.

2. Ahmad, A., Hadi, F., Ali, N. 2014. Effective phytoextraction of cadmium (Cd) with increasing concentration of total phenolics and free proline in Cannabis sativa (L) plant under various treatments of fertilizers, plant regulators and sodium salt. International journal of phytoremediation, 17(1), 56-65.

3. Ali, H., Khan, E., Sajad, M.A. 2013. Phytoremediation of heavy metals - concepts and applications. Chemosphere, 91(7), 869-881.

4. Alkorta, I., Hernández-Allica, J., Becerril, J., Amezaga, I., Albizu, I., Garbisu, C. 2004. Recent findings on the phytoremediation of soils contaminated with environmentally toxic heavy metals and metalloids such as zinc, cadmium, lead, and arsenic. Reviews in Environmental Science and Biotechnology, 3(1), 71-90.

5. Bleecker, A.B., Kende, H. 2000. Ethylene: a gaseous signal molecule in plants. Annual review of cell and developmental biology, 16(1), 1-18.

6. Bulak, P., Walkiewicz, A., Brzezińska, M. 2013. Plant growth regulators-assisted phytoextraction. Biologia plantarum, 58(1), 1-8.

7. Chen, K., Yeh, T., Hsu, Y., Chen, C. 2012. The phytoattenuation of the soil metal contamination: the effects of plant growth relgualtors (GA3 and IAA) by employing wetland macrophyte vetiver and energy plant sunflower. Desalination and Water Treatment, 45(1-3), 144-152.

8. Chiu, K., Ye, Z., Wong, M. 2005. Enhanced uptake of As, Zn, and Cu by Vetiveria zizanioides and Zea mays using chelating agents. Chemosphere, 60(10), 1365-1375.

9. Cristaldi, A., Conti, G.O., Jho, E.H., Zuccarello, P., Grasso, A., Copat, C., Ferrante, M. 2017. Phytoremediation of contaminated soils by heavy metals and PAHs. A brief review. Environmental Technology \& Innovation, 8, 309-326.

10. Denton, B. 2007. Advances in phytoremediation of heavy metals using plant growth promoting bacteria and fungi. MMG 445 Basic Biotechnol., 3, 1-5.

11. Duruibe, J.O., Ogwuegbu, M., Egwurugwu, J. 2007. Heavy metal pollution and human biotoxic effects. International Journal of physical sciences, 2(5), 112-118.

12. Evangelou, M.W., Ebel, M., Schaeffer, A. 2007. Chelate assisted phytoextraction of heavy metals from soil. Effect, 
mechanism, toxicity, and fate of chelating agents. Chemosphere, 68(6), 989-1003.

13. Falkowska, M., Pietryczuk, A., Piotrowska, A., Bajguz, A., Grygoruk, A., Czerpak, R. 2011. The effect of gibberellic acid (GA3) on growth, metal biosorption and metabolism of the green algae Chlorella vulgaris (Chlorophyceae) Beijerinck exposed to cadmium and lead stress. Pol J Environ Stud, 20, 53-59.

14. Fässler, E., Evangelou, M.W., Robinson, B.H., Schulin, R. 2010. Effects of indole-3-acetic acid (IAA) on sunflower growth and heavy metal uptake in combination with ethylene diamine disuccinic acid (EDDS). Chemosphere, 80(8), 901-907.

15. George, E.F., Hall, M.A., De Klerk, G.-J. 2008. Plant growth regulators I: introduction; auxins, their analogues and inhibitors. in: Plant propagation by tissue culture, Springer, pp. 175-204.

16. Greipsson, S. 2011. Phytoremediation. Nature Education Knowledge, 3(10), 7.

17. Hadi, F., Ali, N., Ahmad, A. 2014. Enhanced phytoremediation of cadmium-contaminated soil by Parthenium hysterophorus plant: effect of gibberellic acid (GA3) and synthetic chelator, alone and in combinations. Bioremediation journal, 18(1), 46-55.

18. Hadi, F., Bano, A., Fuller, M.P. 2010. The improved phytoextraction of lead $(\mathrm{Pb})$ and the growth of maize (Zea mays L.): the role of plant growth regulators (GA3 and IAA) and EDTA alone and in combinations. Chemosphere, $80(4), 457-462$.

19. Hsiao, K.-H., Kao, P.-H., Hseu, Z.-Y. 2007. Effects of chelators on chromium and nickel uptake by Brassica juncea on serpentine-mine tailings for phytoextraction. Journal of hazardous materials, 148(1-2), 366-376.

20. Huang, J.W., Chen, J., Berti, W.R., Cunningham, S.D. 1997. Phytoremediation of lead-contaminated soils: role of synthetic chelates in lead phytoextraction. Environmental Science \& Technology, 31(3), 800-805.

21. Israr, M., Sahi, S.V. 2007. Promising role of plant hormones in translocation of lead in Sesbania drummondii shoots. Environmental Pollution, 153(1), 29-36.

22. Järup, L. 2003. Hazards of heavy metal contamination. British medical bulletin, 68(1), 167-182.

23. Jing, Y.-d., He, Z.-1., Yang, X.-e. 2007. Role of soil rhizobacteria in phytoremediation of heavy metal contaminated soils. Journal of Zhejiang University Science B, 8(3), 192-207.

24. Kabata Pendias, A. 2010. Chapter 2. The Anthroposphere. in: Trace elements in soils and plants, CRC press, pp. 5-33.

25. Kamran, M.A., Amna, Mufti, R., Mubariz, N., Syed, J.H., Bano, A., Javed, M.T., Munis, M.F.H., Tan, Z., Chaudhary, H.J. 2014. The potential of the flora from different regions of Pakistan in phytoremediation: a review. Environmental Science and Pollution Research, 21(2), 801-812.

26. Khan, A.S., Chaudhry, N.Y. 2006. GA3 improves flower yield in some cucurbits treated with lead and mercury. African Journal of Biotechnology, 5(2), 149-153.

27. Kida, A., Noma, Y., Imada, T. 1996. Chemical speciation and leaching properties of elements in municipal incinerator ashes. Waste Management, 16(5-6), 527-536.

28. Kos, B., Leštan, D. 2004. Soil washing of $\mathrm{Pb}, \mathrm{Zn}$ and Cd using biodegradable chelator and permeable barriers and induced phytoextraction by Cannabis sativa. Plant and soil, 263(1), 43-51.

29. Kulkarni, M.G., Stirk, W.A., Southway, C., Papenfus, H.B., Swart, P.A., Lux, A., Vaculík, M., Martinka, M., Staden, J.V. 2012. Plant growth regulators enhance gold uptake in Brassica juncea. International journal of phytoremediation, 15(2), 117-126.

30. Leštan, D., Luo, C.-1., Li, X.-d. 2007. The use of chelating agents in the remediation of metal-contaminated soils: a review. Environmental pollution, 153(1), 3-13.

31. Leung, J., Giraudat, J. 1998. Abscisic acid signal transduction. Annual review of plant biology, 49(1), $199-222$.

32. Liphadzi, M., Kirkham, M., Paulsen, G. 2010. Auxin-enhanced root growth for phytoremediation of sewage-sludge amended soil. Environmental technology, 27(6), 695-704.

33. Liu, D., Li, T., Yang, X., Islam, E., Jin, X., Mahmood, Q. 2007. Enhancement of lead uptake by hyperaccumulator plant species Sedum alfredii Hance using EDTA and IAA. Bulletin of environmental contamination and toxicology, 78(3-4), 280-283.

34. López, M.L., Peralta-Videa, J.R., Benitez, T., Duarte-Gardea, M., Gardea-Torresdey, J.L. 2007. Effects of lead, EDTA, and IAA on nutrient uptake by alfalfa plants. Journal of Plant nutrition, 30(8), 1247-1261.

35. Lopez, M.L., Peralta-Videa, J.R., Parsons, J.G., Gardea-Torresdey, J.L., Duarte-Gardea, M. 2010. Effect of indole-3-acetic acid, kinetin, and ethylenediaminetetraacetic acid on plant growth and uptake and translocation of lead, micronutrients, and macronutrients in alfalfa plants. International journal of phytoremediation, 11(2), 131-149.

36. Luo, C., Shen, Z., Li, X. 2004. Enhanced phytoextraction of Cu, Pb, Zn and Cd with EDTA and EDDS. Chemosphere, 59(1), 1-11.

37. Mahar, A., Wang, P., Ali, A., Awasthi, M.K., Lahori, A.H., Wang, Q., Li, R., Zhang, Z. 2016. Challenges and opportunities in the phytoremediation of heavy metals contaminated soils: a review. Ecotoxicology and environmental safety, 126, 111-121. 
38. Meij, R., te Winkel, H. 2007. The emissions of heavy metals and persistent organic pollutants from modern coal-fired power stations. Atmospheric Environment, 41(40), 9262-9272.

39. Nagajyoti, P., Lee, K., Sreekanth, T. 2010. Heavy metals, occurrence and toxicity for plants: a review. Environmental chemistry letters, 8(3), 199-216.

40. Reddy, M.S., Basha, S., Joshi, H., Jha, B. 2005. Evaluation of the emission characteristics of trace metals from coal and fuel oil fired power plants and their fate during combustion. Journal of Hazardous Materials, 123(1-3), 242-249.

41. Ross, S.M. 1994. Toxic metals in soil-plant systems. John Wiley and Sons Ltd. Salt, D.E., Smith, R., Raskin, I. 1998. Phytoremediation. Annual review of plant biology, 49(1), 643-668.

42. Sarwar, N., Imran, M., Shaheen, M.R., Ishaque, W., Kamran, M.A., Matloob, A., Rehim, A., Hussain, S. 2017. Phytoremediation strategies for soils contaminated with heavy metals: Modifications and future perspectives. Chemosphere, 171, 710-721.

43. Sharma, H., Kumar, A. 2011. Effect of plant growth regulators and chemical fertilizers on growth and productivity of Chlorophytum tuberosum and Pergularia daemia. Journal of Medicinal Plants Research, 5(13), 2647-2651.

44. Sidhu, G.P.S., Bali, A.S., Singh, H.P., Batish, D.R., Kohli, R.K. 2018. Ethylenediamine disuccinic acid enhanced phytoextraction of nickel from contaminated soils using Coronopus didymus (L.) Sm. Chemosphere, 205, 234-243.

45. Singh, A., Kuhad, R.C., Ward, O.P. 2009. Biological remediation of soil: an overview of global market and available technologies. in: Advances in applied bioremediation, Springer, pp. 1-19.

46. Sun, Y.-b., Zhou, Q.-X., An, J., Liu, W.-t., Liu, R. 2009. Chelator-enhanced phytoextraction of heavy metals from contaminated soil irrigated by industrial wastewater with the hyperaccumulator plant (Sedum alfredii Hance) Geoderma, 150(1-2), 106-112.

47. Sun, Y., Xu, Y., Zhou, Q., Wang, L., Lin, D., Liang, X. 2012. The potential of gibberellic acid 3 (GA3) and Tween-80 induced phytoremediation of co-contamination of Cd and Benzo [a] pyrene (B [a] P) using Tagetes patula. Journal of environmental management, 114, 202-208.

48. Taiz, L., Zeiger, E., Dressen, U., Hensel, W., Karow, J. 2000. Physiologie der pflanzen. Spektrum Akademischer Verlag.

49. Tandy, S., Schulin, R., Nowack, B. 2006. Uptake of metals during chelant-assisted phytoextraction with EDDS related to the solubilized metal concentration. Environmental science \& technology, 40(8), 2753-2758.

50. Tassi, E., Pouget, J., Petruzzelli, G., Barbafieri, M. 2007. The effects of exogenous plant growth regulators in the phytoextraction of heavy metals. Chemosphere, 71(1), 66-73.

51. Ullah, A., Heng, S., Munis, M.F.H., Fahad, S., Yang, X. 2015. Phytoremediation of heavy metals assisted by plant growth promoting (PGP) bacteria: a review. Environmental and Experimental Botany, 117, 28-40.

52. Vamerali, T., Bandiera, M., Hartley, W., Carletti, P., Mosca, G. 2011. Assisted phytoremediation of mixed metal (loid)-polluted pyrite waste: effects of foliar and substrate IBA application on fodder radish. Chemosphere, 84(2), 213-219.

53. Vangronsveld, J., Herzig, R., Weyens, N., Boulet, J., Adriaensen, K., Ruttens, A., Thewys, T., Vassilev, A., Meers, E., Nehnevajova, E., Lelie, D.v.d., Mench, M. 2009. Phytoremediation of contaminated soils and groundwater: lessons from the field. Environmental Science and Pollution Research, 16(7), 765-794.

54. Wuana, R.A., Okieimen, F.E. 2011. Heavy metals in contaminated soils: a review of sources, chemistry, risks and best available strategies for remediation. Isrn Ecology, 2011.

55. Yao, Z., Li, J., Xie, H., Yu, C. 2012. Review on Remediation Technologies of Soil Contaminated by Heavy Metals. Procedia Environmental Sciences, 16, 722-729.

56. Yeh, T., Kao, C., Chen, W. 2017. Integrated phytoremediation focused on microbial investigation. RSC Advances, 8(9), 4680-4685.

57. Yeh, T., Lin, C., Lin, C., Chen, C. 2014. Chelator-enhanced phytoextraction of copper and zinc by sunflower, Chinese cabbage, cattails and reeds. International Journal of Environmental Science and Technology, 12(1), 327-340.

58. Yeh, T., Yuan, C., Lin, Y. 2016. Biostimulator and biodegradable chelator to pytoextract stubborn soil $\mathrm{Pb}$ and $\mathrm{Ni}$ Journal of the Taiwan Institute of Chemical Engineers, 71, 174-188. 